\title{
IDŐSKORÚAK ÉLETMINŐSÉGE 2010
}

\author{
Patyán LÁszló
}

\begin{abstract}
This study based on the research „Life quality in Nyíregyháza”. The research examined near 2000 households in „panel style" that means we examined the sample every twice years, 2008 and 2010. The study shows the situation of the elder households. The main topics were: the conditions of households, benefits, subjective well-being, health situations, living conditions, costs of living, and housing .

The study showed the special situations of households, where people over 65 years, and lived alone, or together with the other old person.
\end{abstract}

Keywords: elderly,households of elderly, quality of life, sealth status, subjective wellbeing, way of living,, cost of living

DOI: $10.19055 / \mathrm{ams} .2012 .3 / 3 / 8$

\section{BEVEZETÉS}

A tanulmányban Nyíregyháza város időskorú népességének helyzetét igyekszem feltárni. A városi adatok forrása a Nyíregyháza Város Életminősége háztartás panel vizsgálat 2008 és 2010 évi adatfelvétele. A kutatás 2008-ban mintegy 2000 háztartást érintett. Az eredmények megvizsgálását megelőzően azonban mindenképp szükséges felhívni a figyelmet a kérdőívet érintő olyan módszertani változásokra, melyek többek között az időskorú népesség adatbázisba került mintáját is érintette. Az első adatfelvétel során háztartási és személyi kérdőíveket is használtunk. A 2010-es adatfelvétel alkalmával a háztartásfők nyilatkoztak és a háztartásra vonatkozó adatokat ők mondták el a kérdezőbiztosoknak. 2010-ben 1060 háztartásra vonatkozó adat állt rendelkezésünkre. Joggal feltételezhetjük, hogy a második mintából nagyobb számban maradtak ki azok az időskorúak, akik a háztartásban családtagként vannak jelen, akadályozottságuk miatt nem ők válaszoltak a kérdezőbiztosok kérdéseire. Ez a tény várhatóan „aktivizálhatja” az időskorú mintánkat, vagyis a 2008 évihez képest nagyobb lehet az aktív időskorúak aránya.

Az időskorúak életminőségének számos változója közül a jövedelmi helyzet, megélhetés, a fogyasztás, az életminőség szubjektív megélése, az egészségi állapot szubjektív mutatói kerülnek a kutatási jelentés középpontjába. 


\section{A MinTáRóL}

A 2008-as adatfelvétel eredményei szerint ( $\mathrm{N}=1848$ háztartás, $\mathrm{N}=4866$ fö) a megkérdezettek 15,7\%-a volt 65 év feletti lakos. Ez az adat Nyíregyháza város lakosságának az országostól fiatalabb korstruktúrájára utal. (1. ábra)

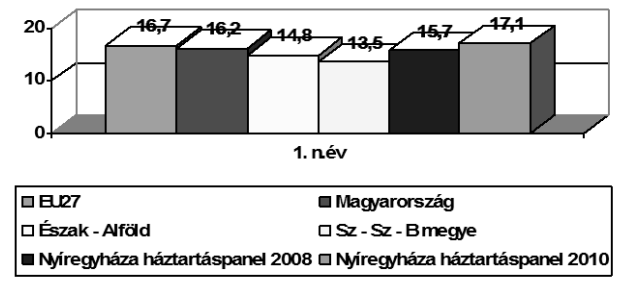

1. ábra - 65 év felettiek aránya a népességben (2008). Forrás: KSH 2008, Életminőség kutatás 2008 - 2010.

A diagramon jól látható, hogy a város kormegoszlási adatai néhány százalékponttal elmaradtak az országos adatokhoz képest. A legfiatalabb korstruktúrát azonban a megyénkben találjuk meg. Az alacsonyabb időskorú ráta jellemzően a népességen belüli egyes csoportok arányából, főként a fiatalok és idősek arányából képződik, de meghatározza a születéskor várható élettartam is. Az öregedési index ${ }^{1}$ 2011-ben hazánkban 115, megyénkben 80, míg Nyíregyházán 91 volt. A városban figyelemreméltó eltérés mutatkozik a férfiak (63) és a nők (120) öregedési indexe között. ${ }^{2}$ A mintába került 1060 háztartásfö $25 \%$-a volt 60 év feletti, $17 \%$-a 65 évnél idősebb és 9,5\%-uk betöltötte már a 70. életévét is a megkérdezés időpontjában.

A 2008 évi adatfelvételhez képest tehát, ahol egyéni kérdőívekkel is vizsgálódtunk, 2010-ben magasabb lesz az időskorúak aránya a mintában, melynek két logikus oka van. Az egyik a 0-18 éves korú fiatalok kikerülése a mintából, mivel ők nem jelennek meg egyéni kérdőíveken, jellemzően a családos háztartásokba kódoldódnak be. A másik ok az időskorú háztartások relatíve magas aránya. A háztartások 17\%-ában csak időskorúak éltek az adatfelvétel időpontjában. Az egyszemélyes háztartások pontosan felében 65 évnél idősebb lakosokat találunk, ez az összes háztartás 6,5\%-a. ${ }^{3}$

A 2. sz. ábra jól szemlélteti az idősek kormegoszlásának sajátosságait. Az adatok szerint a város időskorú lakosságának mintegy 60\%-a a 60-as éveiben járt 2008-ban. 2010-ben a háztartások adatai a következőképpen alakultak. (3. ábra)

1 A 65 év feletti népesség a 0-14 éves népesség százalékában.

2 Az adatok forrása: Malakucziné Póka Mária: Nyíregyháza lakosságának főbb demográfiai jellemzői.

3 Nyíregyháza lakónépességének korstruktúráját pontosan elemzi Malakucziné Póka Mária: Nyíregyháza lakosságának főbb demográfiai jellemzői címmel e kötetben megjelent tanulmánya. 


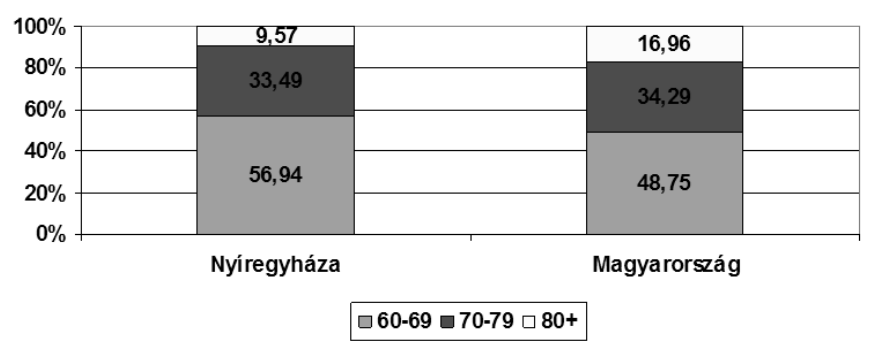

2. ábra - 60 év feletti lakosok aránya korcsoportonként ( $\%$, ahol a $60-\mathrm{x}=100 \%)$. Forrás: KSH 2008, Életminőség kutatás 2008 - 2010.

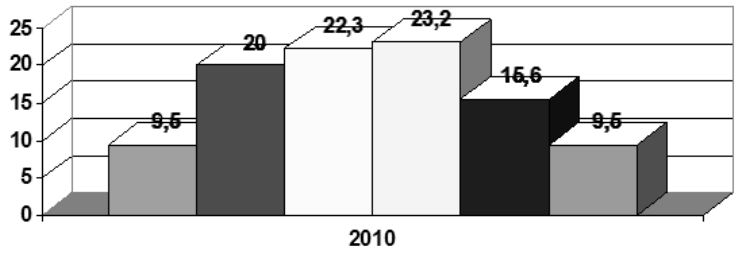

18-29 év $\square$ 30-39 év $\square$ 40-49 év $\square$ 50-59év $\square$ 60-69év $\square 70+e ́ v$

3. ábra - Nyíregyháza város háztartásainak megoszlása a háztartásfők életkora szerint $(\mathrm{N}=1014 ; \%)$. Forrás: Háztartáspanel 2010.

A fiatal, 18 - 29 év közötti családföt tartalmazó háztartások aránya pontosan a 70 év fölötti válaszadók arányával azonos, és minden negyedik háztartásban 60 év feletti volt a kérdőívre válaszokat adó személy. Figyelemreméltó az 50-es éveikben járó háztartásfök magas aránya is, hiszen az elkövetkező években e csoport fog átlépni az idős korcsoportba.

\section{MEGÉLHETÉS}

„,Tisztes nyugdijból (meg)élni...”

Az időskorúak speciális helyzetét fogyasztási preferenciáik, az időskorú háztartások mérete (egy és két fős háztartások magas aránya), valamint háztartási bevételeik jellemzői határozzák meg.

A nyugdíj az időskorúak számára kiemelkedően fontos. Az idősek egyedül élésének, illetve fiatal családtagjaiktól való különélésének kialakulásában, vagyis az időkorúak individualizációjában fontos szerepet játszott az önfenntartó megélhetést biztosító 
nyugdíjrendszer kialakulása (Spéder, 2005). Természetesen lényeges kérdés a nyugdíj mértéke és fizetőértéke. Ha nem elegendő a nyugdíj a megélhetéshez, akkor könnyen válik az időskori szegénység egyik fő okozójává is. ${ }^{4}$ (4. ábra)

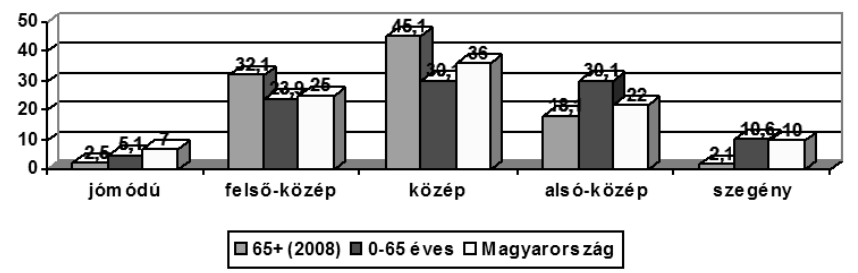

4. ábra - Jövedelmi kvintilisek a háztartási jövedelmek alapján (egy före jutó jövedelem medián értékének százalékában). Forrás: TÁRKI 2008.

A 2008 - évi vizsgálat adatai szerint az időskorúak jól láthatóan a középső jövedelmi ötödbe sorolódtak. Ha a felső-közép és alsó-közép jövedelmi csoportot is figyelembe vesszük, látható, hogy az időskorúak mintegy $95 \%$-a ezen ötödökbe sorolódott.

A helyzet nem változott lényegesen a háztartásföket vizsgáló 2010 évi lekérdezés során sem. Amíg az aktív korúak aránya a legalsó kvintilisben $26 \%$ volt, addig az idős korúaknak csak a 12,8\%-a tartozott ide. A legfelső jövedelmi ötödben azonban fordított a helyzet, hiszen az aktív korú háztartásfók 17\%-a és az idősek 22\%-a tartozott ide. Kiemelkedően magas azonban az alsó ötödbe tartozók aránya az 50 - 59 év közötti népességben, a korcsoport 23,1\% -a tartozott ide. Ennek a csoportnak már komoly gondokat okoz a munkahely megtartása, illetve az elhelyezkedés, de még jellemzően nem jogosultak nyugdíjszerủ ellátásokra.

Már utaltunk rá, hogy a nyugdíj általában az egyedüli jövedelemforrás az időskorúak számára. A foglalkoztatással kapcsolatos adatok tanúságai szerint a nyugdíj (nyugdíjas kor) utáni munkavállalás kifejezetten a magas iskolai végzettségü csoportok esetében gyakori. A mi mintánkban elhanyagolható volt azok száma, akik azt vallották, hogy a nyugdíj mellett, vagy nyugdíjas korban munkát vállalnak $(0,5 \%)$. Az idősek nyugdíjfüggősége tehát jelentős. (5. ábra)

A 2010 évi minimális nyugdíj 28.500 Ft volt. Az egy före eső jövedelmek rátájában azért célszerü e számot figyelembe venni, mert a legtöbb szociális támogatási forma jogosultsági kritériuma ennek százalékában kerül meghatározásra. A táblázatból jól látszik, hogy az időskorút tartalmazó háztartások igen alacsony arányban élnek meg ennyi havi egy före jutó összegből. Ez érthető is, hiszen a legfőbb jövedelemforrás a nyugdíj az idősek körében. Az ide sorolódott idősek aránya néhány százalékos, valószínűleg nem saját jogon szerzett jogosultság alapján kapják nyugdíjukat. Jóval maga-

4 Lásd részletesen: Anne-Marie Guillemard(1999): Megöregedés és kirekesztetté válás, Szociológiai Figyelö II-III. 1-2. sz. és Spéder Zsolt: Európai Családformák változatossága címú műveit. 
sabb viszont az aktívkorú háztartások aránya e kategóriában. A gyermekek számának emelkedésével a szegénységkutatások hazai eredményeit támaszthatjuk alá. A gyermeküket egyedül nevelök $9 \%$-a, a két gyermeket egyedül nevelök közül pedig minden ötödik aktív korúnak ilyen alacsony jövedelemből kell megélni.

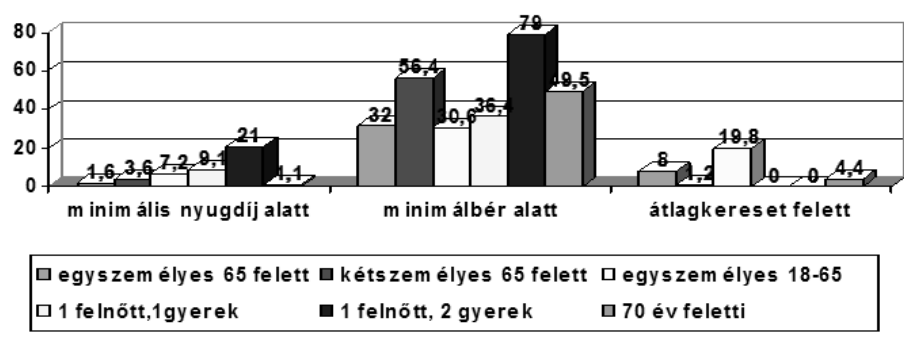

5. ábra - Egyes háztartástípusok egy före eső jövedelme bizonyos jövedelmi viszonyszámok tükrében 2010. (\%). Forrás: Háztartáspanel 2010.

A minimálbér 2010-ben Magyarországon nettó 73.500 Ft volt. Ennél kevesebb egy fóre eső jövedelme az egyszemélyes időskorút tartalmazó háztartások harmadának volt, a kétszemélyes háztartásban élők több mint felének. Ebbe a csoportba tartozott a 70 évnél idősebb háztartásfők mintegy fele is.

A 2010 évi átlagkereset nettó $135.200 \mathrm{Ft}$ volt hazánkban. Ennél több jutott az egyszemélyes aktív háztartásfők 20\%-ának és az egyszemélyes időskorú háztartásfők 8 százalékának.

A nyugdíj, mint megélhetést biztosító jövedelemforrás paradox módon még akkor is nagy jelentőséggel bír, ha tudjuk, hogy az átlagnyugdíjak térségünkben elmaradnak az országos átlagtól. A KSH adatai szerint 2009-ben például 83.689 Ft volt az átlagnyugdij mértéke hazánkban, a megyénkben azonban csak 67.689 Ft-tal lehetett számolni. A problémák okát valószínüleg az aktív korúak terheiben (pl. gyermeknevelés) és a foglalkoztatás rátáiban kell keresni. 2009-ben országosan 10\%-os munkanélküli ráta mellett megyénk rátája 19,1\%-ra rúgott (KSH, 2009).

A vizsgált időszakban (2008 - 2010) a nyugdíjak drasztikus változásával nem kellett számolni, de folyamatosan emelkedtek a megélhetés költségei, így érdekes lehet, hogyan vélekedtek jövedelmi helyzetük változásáról a megkérdezett időskorúak. (6. ábra)

A diagram adatai szerint az idősek jövedelemi helyzete saját megítélésük szerint romlott. A változás arányosan igazodott az aktív korosztály véleményéhez, mindössze annyi különbséggel, hogy az aktív korúak közül többen érezték helyzetüket változatlannak.

A kérdőív egy másik részét csak az időskorúaknak kellett kitölteni. A kérdések egy csoportja az élethelyzet szubjektív megítélésére irányul. A kérdések (állítások) Likert értékeket kaptak, így a válaszadók 1-5-ig értékelhették azokat az iskolában szokásos módon. Az állítások átlagának összehasonlítása azonban nem hozott lényeges eltérést két év távlatában. Az idősek saját helyzetüket itt is átlagosan ugyanúgy közepesre (nem jobb, nem rosszabb) értékelik, mint 2008-ban tették. 


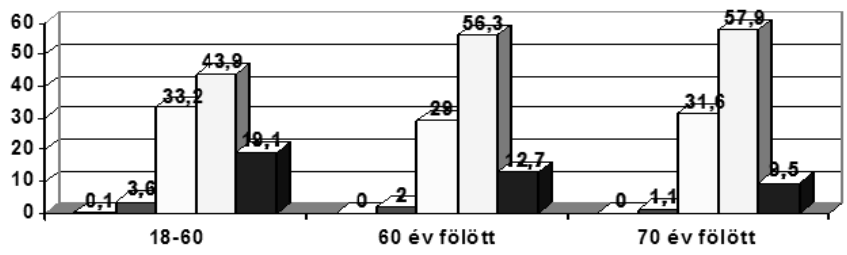

$\square$ Jelentösen javult $\square$ javult $\square$ nem változott $\square$ rosszabb lett $\square$ sokkal rosszabb lett

6. ábra - Hogyan változott jövedelmi helyzete az elmúlt évhez képest? (A válaszok \%-ában). Forrás: Háztartáspanel 2010.

\section{A FOGYASZTÁS JELLEMZÖI}

„Elöször félretesszük a rezsit, utána a gyógyszerre, a maradékból veszünk élelmiszert meg támogatjuk a gyerekeket..."

Az időskorúak rétegződését vizsgáló korábbi háztartás/időmérleg kutatás adatai a lakhatás, fogyasztás és anyagi helyzet alapján rétegezte az időseket (Bukodi, 2004). A kutatás eredménye szerint a legrosszabb helyzetben lévő un. „depriváltak” rétegét 11\%-ra becsülték, a „tisztes szegények” csoportját pedig 21\%-ra. Az idősek további 14\%-ának nem megfelelő a lakása (méret, komfort, vagy fenntartási költségek). Fogyasztása alapján felső osztályba tartozott az idősek 2\%-a. A ,depriváltak”, a „tisztes szegények” és a „nem megfelelő lakhatásban élők” arányát figyelembe véve tehát az idősek mintegy fele nem tud szabadidőre, kultúrára költeni és a mindennapi fogyasztás szintjén is be kell osztaniuk nyugdíjukat. A fogyasztási preferenciák fontossági sorrendben a következök voltak: lakhatáshoz füződő kiadások fedezése, egészségügyi és gyógyszerköltségek fedezése, majd az élelmiszer költségek kifizetése.

A napi költségek fedezésén túl más preferenciák is jellemzőek az idősek esetében. Egy, az időskorúak szubjektív életminőségét vizsgáló kutatás (Giczi, 2008) tapasztalatai szerint az idősek hangulatát - többek között - alapvetően befolyásolja a gyermekeik megélhetése iránt érzett felelösség, aggódás.

A fogyasztás jellemzőivel kapcsolatos kérdésekre adott válaszok átlaga nem változott jelentősen a 2008 évi adatfelvétel óta. (7. ábra)

Az egyes állítások átlagai között egy százalékpontot meg nem haladó eltérések mutatkoznak. Kétségtelen, hogy az időseket azok a költségek aggasztják leginkább, amelyek a napi megélhetéssel hozhatók összefüggésbe (pl. élelmiszer), illetve amelyek emelkedésével szemben kiszolgáltatott az időskorú (lakhatás költségei). A helyzet két év alatt nem változott, az idősek legneuralgikusabb kiadása még mindig a lakhatással kapcsolatos kiadások köre. 
A család, gyermekek anyagi támogatásával kapcsolatos állítás átlaga emelkedett ugyan, de még így is csak 2,56 volt.
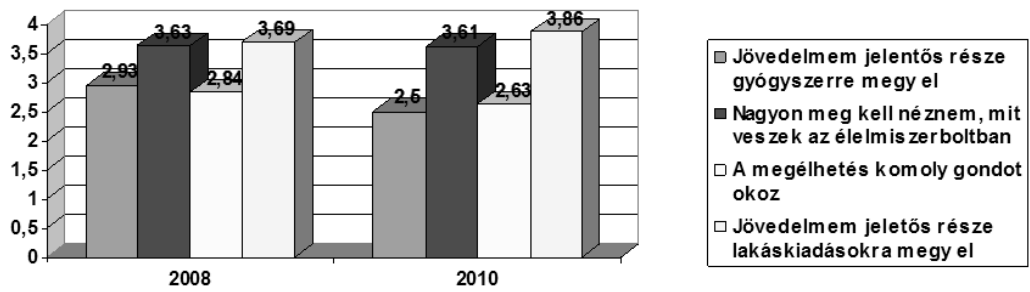

7. ábra - Időskorúak fogyasztással kapcsolatos vélekedéseinek átlaga 2008 - 2010. Forrás: Háztartáspanel 2008.- 2010.

\section{SZUBJEKTÍV JÓLÉT}

„Rosszabbul élünk, mint két éve?...”

Giczi Johanna többváltozós elemzéssel igyekezett az idősek szubjektív jólétét legjobban meghatározó tényezőket összeállítani. Kutatásában az elidegenedés, segítség hiánya, depresszió és magány jellemzőkből indult ki (Gizci, 2008). A vizsgálat eredményeképpen az idősek szubjektív jólétének legerősebb változói sorrendben a következők voltak:

- $\quad$ szeretett társ elveszítése;

- szegénység;

- aggodalom gyermekük jövője miatt.

A korábbi feltételezésekhez képest nem volt jelentős a lakhely (településtípus) és az egészségi állapot változója.

Saját vizsgálatunkban a szubjektív jólét dimenzióit az alábbi fö kérdéscsoportokkal igyekeztünk megvizsgálni:

- Akadályozottság, kompetenciák korlátozódása

- Elidegenedés- érzés

- Elfogadás, megbecsültség

- Részvétel, aktivitás

Az akadályozottság kérdéscsoporthoz tartoztak az életkorral, valamint az egészségi állapot romlásával kapcsolatos ítéletek, a másokra való támaszkodás kényszere. Az elidegenedés-érzés kérdéscsoportban a világ dolgaiban való eligazodás, a magány, félelem témaköreit kellett értékelni az időseknek. A részvétel és aktivitás témakörben egyaránt megjelentek a pozitív (pl. annyi mindent adhatnék másoknak), és negatív értékeket hordozó állítások (az ember nyugdíj után már nem való semmire). (8. ábra) 

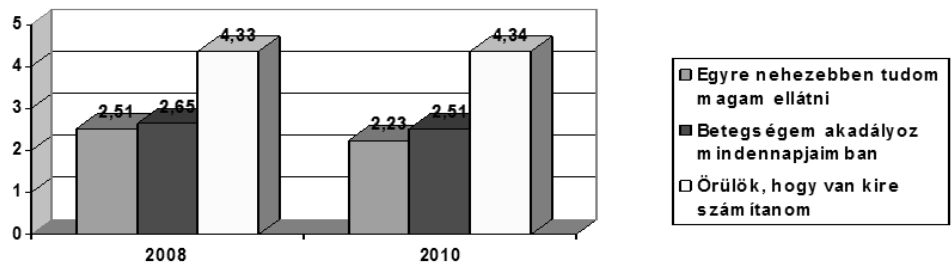

8. ábra - Akadályozottság kérdések átlagai 2008-2010. Forrás: Háztartáspanel 2008.- 2010.

Az öregedés, betegség miatti akadályozottság élménye nem annyira meghatározó az időskorúak értékelése szerint. Figyelemreméltó azonban a támogatás, jellemzően a mechanikus szolidaritás iránti igénye az időseknek, ami azt jelenti, hogy nehéz helyzetükben sokkal inkább bíznak a vér szerinti hozzátartozóikban. ${ }^{5}$

Az elidegenedés témakörben a ,gyakran félek egyedül” állítás a magányosan élö időskorúak magas aránya ellenére alacsony átlagot kapott (1,93). A kérdés megítélése két év távlatában nem változott. Hasonlóan alacsony pontokat adtak az idős emberek a „, modern világ dolgaiban nehezen igazodom el” állítás is (3,03). (9. ábra)
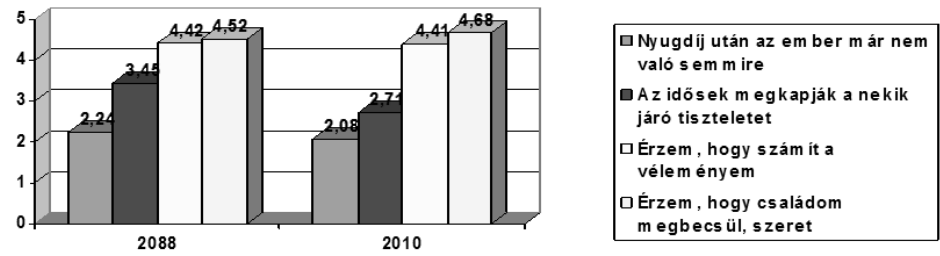

9. ábra - Idősek társadalmi elfogadása. Forrás: Háztartáspanel 2008.- 2010.

A 8. sz. ábrán is látható volt, itt is megerősíthető a család támogató szerepének elsődlegessége. Az idősekkel kapcsolatos általános vélekedések értékelésének figyelembe vételével megállapítható, hogy az időskorúak jobban értékelik a helyi kapcsolatok jelentőségét és abban elfoglalt helyüket, a részvétel jelentőségét. (10. ábra)

A kérdéscsoport állításai a két lekérdezés alkalmával szinte ugyanolyan átlagokat kaptak. A legmagasabb átlagokat adó állítások az időskorúak nyitottságára, erőforrásaik kiaknázatlanságára hívják fel a figyelmet.

5 Durkheim a szolidaritás két típusát különbözteti meg, a mechanikus és az organikus szolidaritást. Az előző az értelmezésünkben a család és rokonság által nyújtott segítség, támogatás, míg az utóbbit az intézmények, szervezetek által biztosított támogatásként fogjuk fel. Részletesen: Durkheim E. (1986): A társadalmi munkamegosztásról MTA Szociológiai kutatóintézet. 
Összességében a 2010 évi vizsgálat szubjektív jólétre vonatkozó kérdései alapján megállapítható, hogy az idősek nem látják pesszimistábban a világot. A támogató rendszerek, ezek között is a család nem veszítette el meghatározó jelentőségét. Kimagasló átlagokat kaptak továbbá az idősek aktivitásának kérdéseit feszegető állítások.
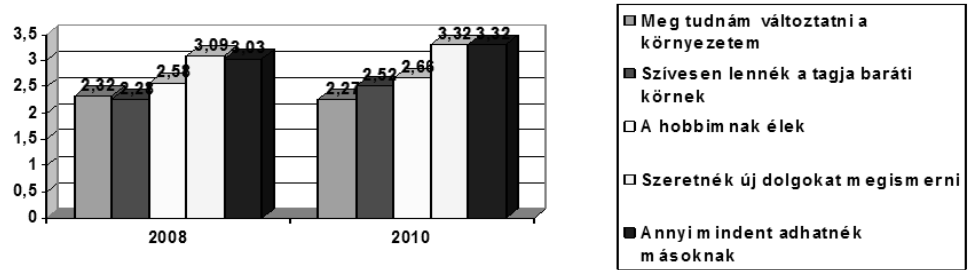

10. ábra - Aktív idős korra vonatkozó kérdések. Forrás: Háztartáspanel 2008.- 2010.

\section{AZ EGÉSZSÉGI ÁLLAPOT MUTATÓI}

„Ha 60 év fölött nem ébredsz fájdalommal, az azt jelenti, meghaltál..." (ismeretlen szerzö)

Az életkor elörehaladtával nő az esélye az egészségi állapot romlásának. Az Országos Lakosság Egészségfelmérés ${ }^{6}$ (OLEF) 2003 évi adatai szerint a 65 év feletti korcsoport feletti népesség $80 \%$-a szenved valamilyen krónikus betegségtől, az időskorúak 17,4\%-a cukorbeteg. Az időskorúak fele él együtt reumával, vagy ízületi gyulladással, az idős nők 25\%-ának van csontritkulása. A 2001 évi népszámlálás adatai szerint a lakosság 5,5\%-a jellemezte magát fogyatékkal élőként. A 65 - 69 éves korosztály esetében ez a ráta 9,8\% volt, a 75 éven felüliek esetében pedig már $16,4 \%{ }^{7}$. A térségben tapasztalható alacsony születéskor várható élettartam miatt joggal várható, hogy a nyíregyházi idős korosztály rosszabb egészségügyi paraméterekkel fog rendelkezni. (11. ábra)

Az időskorban gyakoribb megbetegedések köréből a mozgásszervi és érzékszervi megbetegedéseknek a nyíregyházi mintában is magas az aránya.

Az OLEF vizsgálatai szerint időskorban jelentősen megnő az esély a magas vérnyomás kialakulására. A 65 év fölötti nők több mint hétszeres, a férfiak három és fél szeres gyakorisággal szenvedhetnek a betegségtől. Az országos mintában szereplő idős nők $60,4 \%$-át a férfiak 45,2\%-át kezelték magas vérnyomás miatt a vizsgálatot megelőző évben. A nyíregyházi vizsgálatban a 65 év feletti lakosság 71,2\%-a kapott kezelést 2008-ban magas vérnyomás miatt.

6 Országos Lakosság Egészségfelmérés Kutatási Jelentés 2006. Országos Szakfelügyeleti Módszertani Központ 2006. (Krónikus betegségek) www.oszmk.hu

7 KSH 2001. A kérdés az idősek szubjektív egészségi állapotára utalt: „Fogyatékosnak érzi - e magát?" 


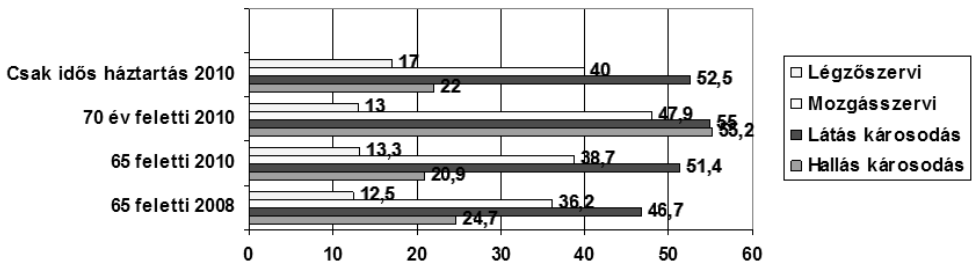

11. ábra - Kezelték - e az előző évben az alábbi betegségekkel? (\%). Forrás: Háztartás panel 2008.- 2010.

A 2008 évi felmérés adataihoz képest nem emelkedett a kezeléseken átesett idősek számaránya, de jól láthatóan emelkednek a ráták az életkor elörehaladtával arányosan. A válaszadó idősek $72 \%$-ának volt ilyen problémája a kérdezést megelőző esztendőben. A 70 éven felüli korosztály $76 \%$-a állt ilyen típusú kezelések alatt. (12. ábra)
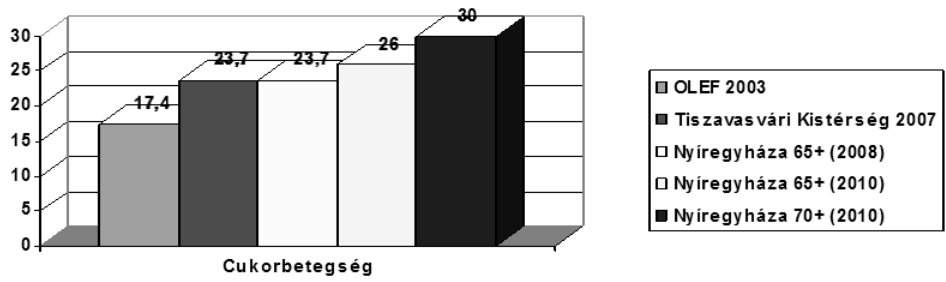

12. ábra - Kezelték e cukorbetegség, vagy magas vércukorszint miatt?(\%). Forrás: Háztartáspanel 2008.- 2010.., OLEF, MikrOLEF adatok forrása: www.oszmk.hu

A magas vérnyomás és a cukorbetegség számos szövődménnyel járó megbetegedés, mellyel együtt lehet élni, de időskorban komolyan befolyásolhatja a teljesítőképességet, az életminőséget.

\section{SZUBJEKTÍV EGÉSZSÉGMUTATÓK}

„,Vagyogatunk öregesen, betegesen ...”

Az egészségi állapot romlása az életkor előrehaladtával szignifikáns összefüggést mutat. A megbetegedések között az érzékszervi problémák, a mozgásszervi rendszer rendellenességei, keringési és anyagcserezavarok a legjellemzőbbek. Visszatérő betegséggel küzd az idősek 70\%-a, a hetven év fölötti népesség 79\%-a. A 65 évnél idősebbek mindennapi életének velejárója az egészségügyi problémák megélése, illetve az ezzel 
való együttélés. Betegség miatt akadályozottnak érzi az életét az idősek több, mint fele. Súlyosabb problémával küszködik (kórházi ápolás, ágyhoz kötöttség) az idősek 13\%-a. (13. ábra)

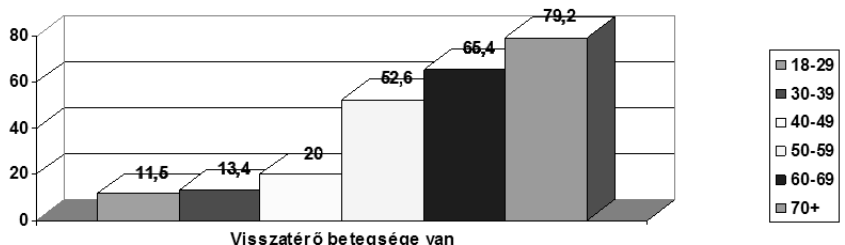

13. ábra - Visszatérő betegséggel él együtt (\%). Forrás: Háztartáspanel 2008.- 2010.

Az idősek szubjektív jólétét vizsgáló kutatások szerint az egészségi állapot romlása nem tekinthető meghatározó változónak (Giczi, 2008), talán azért is, mert ezzel az idő seknek tartósan együtt kell élniük. A nyíregyházi mintában a saját egészségi állapot megítélésével kapcsolatos vélekedések a következőképpen alakultak - 14. ábra.

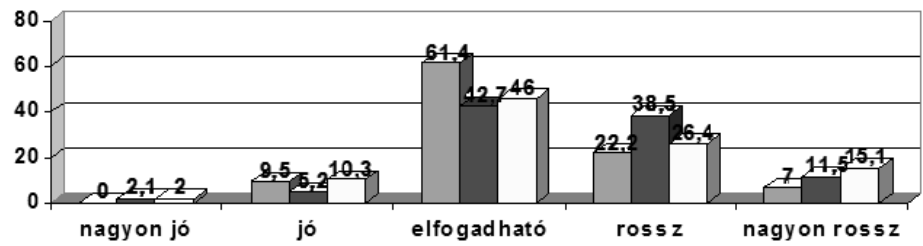

$\square$ 60-69 éves $\square 70$ év feletti $\square$ mikoLEF 2007 idös korú

14. ábra - Milyennek tartja saját egészségi állapotát? (\%). Forrás: Háztartáspanel 2010, MikrOLEF adatok forrása: www.oszmk.hu

A rosszabb egészségmutatók ellenére a 60 -as éveikben járó időskorúak jelentős része elfogadhatónak, vagy jónak ítéli meg egészségi állapotát, a 70 évnél idősebbek $42 \%$ azonban már rossznak és nagyon rossznak ítéli meg az egészségét.

Az egészségügyi ellátás igénybevételének gyakorlatában szintén találunk az életkorral korreláló összefüggéseket. Az aktív korosztály tagjai kevesebbet betegeskednek, de jellemzően ennek arányához képest is ritkábban fordulnak orvoshoz. Az időskorúak esetében gyakoribb az egészségügyi ellátás igénybevétele abban az esetben is, ha kisebb problémákkal küzdenek, vagy nincsen kifejezett betegségük. Az idősödéssel romló egészségi állapot fokozottabb anyagi kockázatot hordoz magában, melyet figyelembe kell venni a célcsoport helyzetének megítélése során. (15. ábra)

A diagram tanúságai szerint az időskorúak több, mint kétszer gyakrabban fordulnak orvoshoz kisebb problémák fennállása esetében is. Az OLEF kutatás szerint az 
egészségügyi ellátás igénybevételében az életkoron kívül meghatározó változó a nemek szerinti hovatartozás is. A nők gyakrabban fordulnak orvoshoz, mint a férfiak, az aktív korúakra inkább jellemző a betegségek esetén az orvoshoz fordulás halogatása, vagy öngyógyító módszerek alkalmazása.

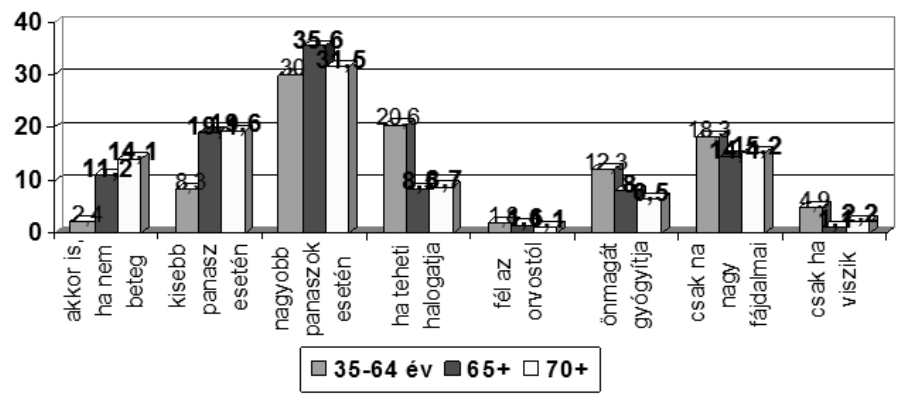

15. ábra - Mikor fordul orvoshoz? (\%). Forrás: Háztartáspanel 2010.

Az egészségügyi szolgáltatások igénybevétele tekintetében az látható, hogy a városi időskorúak ugyanolyan gyakorisággal veszik igénybe a háziorvosi ellátást, mint vidéki kortársaik. ${ }^{8} \mathrm{~A}$ háziorvosi ellátás igénybevételének jellemzőit az alábbi ábra mutatja 16. ábra.

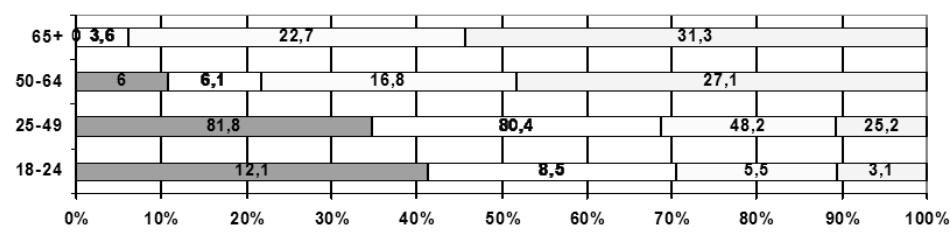

$\square 0 \square$ egy - öt $\square$ hat - tíz $\square$ tizenegy - tizenöt $\square$ tizenötnél több

16. ábra - Háziorvos látogatásának gyakorisága a vizsgálatot megelőző évben. Forrás: Háztartáspanel 2010.

Az időskorúak harmada havi rendszerességgel, vagy gyakrabban látogatja háziorvosát. A szakorvosi ellátás és a kórházi kezelés gyakorisága is korrelál az életkorral, minél idősebb valaki, annál nagyobb az esélye, hogy a vizsgálatot megelőző évben kezelték az intézményekben. Az egészségi állapot, az egészségügyi ellátás használata és az életkor szinte minden esetben szignifikáns összefüggéseket mutatott, mindössze egy helyen volt eltérés prognosztizálható, ez pedig a kórházban töltött napok száma. Az idősebbek egyre kevesebb napot töltenek kórházban a romló egészségi állapotuk ellenére.

8 Az adatokat a MikroLEF 2007 évi kistérségi adataival vetettem össze. 


\section{TÁRSAS KAPCSOLATOK IGÉNYE}

„Elleszünk mi kettecskén...”

A szubjektív jólét egyik legfontosabb változója az időskorúak esetében a társas kapcsolatok - házastárs - megléte és a támogató családi kapcsolatok jelentősége. Giczi Johanna kutatásában a szubjektív jólét legerősebb változójaként említette a házastárssal való együttélést, vagy annak elveszítését. Saját kutatásunk 2008-as adatai szerint az időskorúak előnyben részesítik problémáik megoldása során a házastársat, másodsorban leánygyermeküket, fiúgyermeküket, illetve annak feleségét. Ezen kapcsolatok kimerülése esetén a testvér, a szomszédok és a barátok jönnek sorba. (17. ábra)

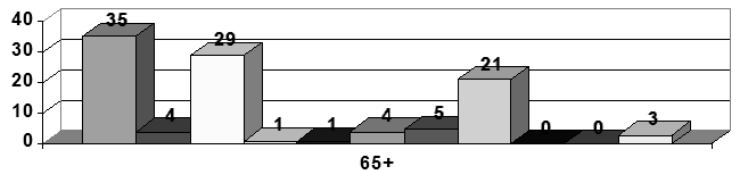

\begin{tabular}{|c|c|c|c|}
\hline$\square$ házastárs & Qélettárs & $\square$ gyermek & $\square$ unoka \\
\hline — szülök & $\square$ tes tvér & $\square$ egyéb rokon & $\square$ barát \\
\hline munkatárs & 口s zervezet képviselöje & $\square$ egyéb & \\
\hline
\end{tabular}

17. ábra - Betegsége esetén kihez fordulna? Forrás: Háztartáspanel 2010.

A mechanikus szolidaritás iránti erőteljes igény a család - és szociálpolitikai diskurzusok középpontjába kerülhet az elkövetkező évtizedekben. Továbbra is meglepő az organikus szolidaritás rendszereivel, szervezeteivel kapcsolatos bizalmatlanság. A 2008 as adatfelvétel szerint az idősek 0,7\%-a venné igénybe elsősorban szociális intézmény támogatását abban az esetben, ha segítségre lenne szüksége. Másodsorban - ha az elözőekben megjelölt támogató nem tud segíteni - az idősek 2,6\%-a kérne támogatást szociális szervezettöl. Sokkal nagyobb a bizalmatlanság a fizetett segítőkkel kapcsolatban. Első sorban az idősek 0,4\%-a venne szolgáltatásokat a piacon, másodsorban ezt a lehetőséget egyetlen időskorú sem választotta.

\section{LAKÁS, LAKHATÁS}

„Életünk munkája eredménye...”

Ahogyan az már korábban is látható volt, az időskorúak lakhatással kapcsolatos helyzete több szempontból is meghatározó tényezője az életminőségnek. Az egy és kétszemélyes háztartások magas aránya, a 70 évnél idősebb korosztály növekvő aránya, az idősebb emberek önellátási kapacitásának csökkenése mellett a megfelelö minőségü és nagyságú lakás is befolyásolja az idősek megélhetését, mindennapjait. 
A kutatás szempontjából vizsgáltuk a lakások nagyságát, ellátottságát, állapotát, a lakókörnyezet minőségét, valamint a lakhatás költségeit. A vizsgálatban külön változóként szereplő egy és kétszemélyes csak időskorút tartalmazó háztartásokat külön is megvizsgáltuk. (18. ábra)
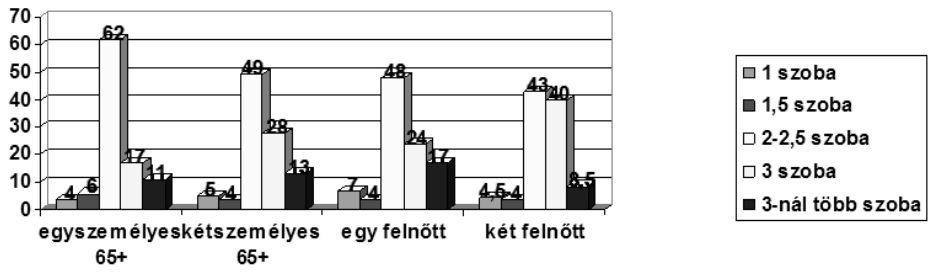

18. ábra - Időskorú és nem időskorú háztartások lakásnagysága a háztartások arányában (\%). Forrás: Háztartáspanel 2010.

Az egyedül élő időskorúak 62\%-a kétszobás lakásban él, majdnem harmaduk pedig három szobás, vagy annál nagyobb lakást birtokol. A két idős emberből álló háztartások 41\%-a három szobás, vagy annál nagyobb lakásban él. Az időskorúak relatív lakásnagysága komoly lakásfenntartási terheket ró a 65 év feletti korosztályra. A lakások több, mint fele távhővel fütött, tíz százaléka egyedi hagyományos rendszerü fütéssel van ellátva. Az idősek 14\%-ának megítélése szerint a lakás hibája nehezíti életvitelüket. 11\% gondolta úgy, hogy lakása szükös (teljes minta átlaga: 9,5\%), 14\%-ukat zavarja a szomszédság, a teljes minta átlagának mintegy kétszerese az aránya azoknak, akik szerint zavaró a lakókörnyezet, 10\%-uk szerint nagy hibák vannak a lakásban (pl. lyukas a tetö), a teljes minta átlagának másfélszerese a vandalizmus miatt panaszkodó idősek aránya.

Az egyedül élő idősek 44,7\% a nagyon megterhelőnek tartja a lakhatással kapcsolatos kiadásait. A kétszemélyes háztartásban élő idősek esetében $28 \%$ ez az arány.

A fenti jellemzők jól mintázzák az időskorúak lakhatással kapcsolatos érzékenységét, valamint a lakhatási költségek relatív súlyának okait. (19. ábra)

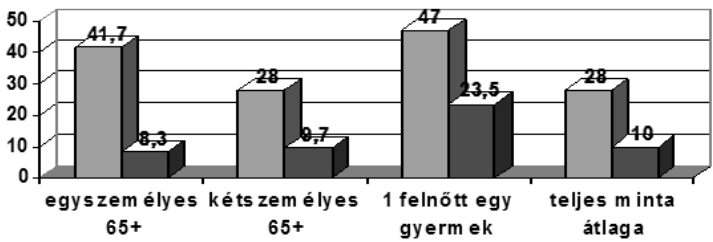

$\square$ Nagyon m egterhelö a lakásfenntartás $\square$ Lakhatási tám ogatás t kapott az elm últ évben

19. ábra - Lakással összefüggő kiadások megítélése és a lakhatási támogatás mértéke (\%). Forrás: Háztartáspanel 2010. 
A táblázat az egyszemélyes időskorúakat tartalmazó háztartások egyenlőtlen helyzetét mutatja. Ennek a hozzáférési egyenlötlenségnek számos oka lehet, az egyik például a relatív lakásnagyság, amit a helyi rendelet preferál. Az idősek nagyobb lakása, illetve a magasabb jövedelem (nyugdíj) így kizárhatja a célcsoportot a támogatásból. (20. ábra)

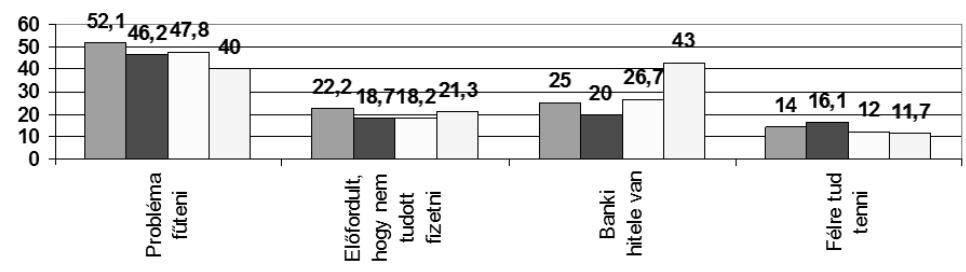

$\square$ Egy személyes $65+\square$ kétszemélyes $65+\square 60$ év fölötti háztartásfő $\square$ minta átlaga

20. ábra - Lakással kapcsolatos állitások megítélése (\%). Forrás: Háztartáspanel 2010.

A lakhatással kapcsolatos költségek megítélésében az idősek a fütéssel kapcsolatos terheket tekintik a legnagyobbnak. Valószínűleg a költségek fedezésének egyik módja a fütés korlátozása egyes helyiségekre, amennyiben erre lehetőség van. A fizetésképtelenség mindezek ellenére a vizsgált csoportok esetében 20\%- körül mozog, életkortól függetlenül. A banki hitelek igénylése minden negyedik időskorú háztartást érint (ebbe tartoznak a közös teherviselések a gyermekekkel is).

A lakhatási terhek közül a hóvégi fizetésképtelenség az aktív korúakat tartalmazó és a gyermeket nevelő háztartások esetében fordul elő sokkal gyakrabban. Az egy felnőttből és két gyermekböl álló családok esetében $50 \%$, két felnőtt és négy gyermek esetében $71,4 \%$, a többgenerációs családok esetében $50 \%$-os az esetenként fizetésképtelen háztartások aránya.

\section{LAKÁS FELSZERELTSÉGE, ELLÁTOTTSÁGA}

„Kattints rá, nagyi..."

A lakás felszereltségét tekintve nem találunk lényeges eltéréseket az egyes háztartások típusai között. Bizonyos fogyasztási eszközök mára már teljesen elterjedtek, normál velejárói a háztartásnak (televízió, mosógép, stb.). A kutatás során az idősek információs technológiai eszközökkel (IKT) való ellátottságát helyeztük a középpontba. A szolgáltatások információs technológia segítségével való fejlesztése az Európai Unió tagállamaiban divatos témává vált, fontos tehát ismerni, hogy az idősek mennyire barátkoztak meg azokkal az eszközökkel amelyeket a szolgáltatások segítésére lehet felhasználni. (21. ábra)

A személyi számítógépet birtokló idősek száma majd' a duplájára nőtt két év leforgása alatt, de még ez az arány csak a fele a városi mintáénak. Az Internet szolgáltatással rendelkezők aránya hasonlóan alakult. Az egy, vagy kétszemélyes háztartások esetében 
azonban két év leforgása alatt nem következett be olyan látványos fejlődés, mint a családban élő 60 év felettiek esetében. A gyermekkel rendelkező családok adatait is figyelembe véve - ahol a legmagasabb a Netet használók aránya - látható az időskorúak hátránya. Amíg a városi mintában 20\%-al nőtt a szolgáltatást használó háztartások aránya, addig az idősek esetében mindössze öt százalékpontos emelkedés figyelhető meg.
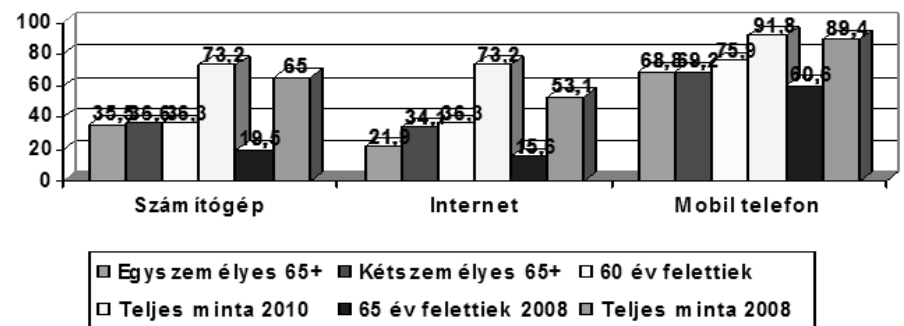

21. ábra - Időskorú háztartások felszereltségének néhány mutatója (\%). Forrás: Háztartáspanel 2010.

Sokkal jobb a helyzet a mobiltelefon szolgáltatással rendelkezők esetében. A városi minta mintegy három százalékpontos emelkedése azért nem meglepö, mert lassan azt mondhatjuk, hogy a mobilszolgáltatás olyan felszereltsége lesz a háztartásoknak, mint a televízió, vagy a mosógép. A teljes minta $92 \%$-a rendelkezett vele 2010 -ben. Az idősek rátája két év alatt 8 százalékpontos emelkedést mutatott, a csak idősböl álló háztartások esetében is közelíti a hetven százalékot.

\section{MobiLITÁs}

„Az idös fát nem lehet átültetni ...?”

A vizsgált intervallumra tehető az un. pénzügyi válság kialakulása, mely különös terheket rótt a háztartásokra, föképpen azok esetében, akik devizahiteleket törlesztenek. A fenti adatok szerint ez a családok $43 \%$-át, az idős háztartások $25 \%$-át érintette. Joggal feltételezhető, hogy a terhek elviselése érdekében a különélő generációk összeköltözhetnek. A „költöztek - e Önhöz” címü kérdésre válaszoló időskorúnak mindössze 2,2\%-a nyilatkozott úgy, hogy 60 éves kora után költözött valaki a háztartásába. A 2010-es adatfelvétel során a magányos idősek 3\%-ához költöztek, a hatvan évnél idösebb háztartásfövel rendelkező háztartások esetében 3,9\% válaszolt igennel.

Az időskorúak nem megfelelö lakhatási viszonyai között szokták említeni a lakásmobilitásra való hajlam hiányát, mint időskori jellemzőt. Ennek némiképp ellentmond a kutatásunk eredménye, mi szerint az időskorúak 15,1\%-a költözött 60 éves kora után (2008). 2010-ben ez az adat 11,9\% volt. Az arány csökkenése vélhetően a bevezetőben 
említett módszertani okokkal magyarázható, itt csak a háztartásfők válaszoltak a kérdésre, a költöző időseket vélhetően családtagként tartják nyilván.

A legjellemzőbb okok fontossági sorrend szerint:

- Az egészségi állapot romlása: Az egészségi állapot romlása több okból is indukálja a mobilitást. Leggyakoribb indok a költözés motivációja mögött a megváltozott állapotnak nem megfelelő felszereltségü, vagy elhelyezkedésü lakás. Az időskorúak lakta lakások gyakran blokkházak emeletein találhatók, ahol az idős az egészségromlás után már nem tud megfelelően közlekedni, különösen akkor, ha nincsen lift (pl. 4 emeletes házak). Az egészségromlás miatti költözés másik leggyakoribb oka a felügyeletre szorulás. A felügyeletre, vagy gondozásra szoruló idősek jellemzően inkább költöznek, mint hogy hozzájuk költözzenek.

- Kisebb lakásra cserél: Kisebb lakás alacsonyabb fenntartási költség mellett lakható. A nagy lakások, különösen a távhővel fütöttek igen magas rezsi költséget terhelnek a bennlakókra és a fogyasztást is csak bizonyos keretek között lehet korlátozni. A KSH 2003 évi jelentése szerint az időskorúaknak komoly megterhelést jelent a lakásfenntartás. Az idősek 25\%-ának mindig, 18\%-ának időközönként, 37\%ának télen komoly megterhelést jelent a lakás fenntartási költségek kifizetése. Az időskorú háztartások több, mint fele megtakarítási céllal korlátozza, vagy korlátozná fogyasztását. A legtipikusabb spórolási forma, amikor az idős csak egy szobát füt, vagy távfütéses lakásban az átalánydíjas gáztüzhelyet üzemelteti fütésként. A kérdőív fogyasztással kapcsolatos fejezetei között található kérdések között a lakás fütésével kapcsolatban az idősek fele nyilatkozott úgy, hogy komoly problémát jelen az életében a rendszeres fütés. Sajnálatos, hogy lakásmobilitásra nem léteznek ösztönző támogatások (pl. illetékmentesség, stb.).

- Biztonság, kellemesebb környék iránti igény: Az időskorúak a nyugdíjba vonulást követően választhatnak az életüknek, igényeiknek megfelelőbb kedvezőbb lakhatási feltételeket. Az egyik leggyakoribb ilyen költözési forma a lakótelepröl kertvárosi (külvárosi) övezetbe költözés.

- Megözvegyülés, nyugdíjazás: A család szerkezetében bekövetkező változások közül az egyik legkomolyabb traumát a társ elvesztése okozza. A családi szerkezet megváltozása mellett ez természetesen a lakásegység fenntartásával kapcsolatban is fokozottabb terhelést jelent a magára maradónak.

- „Családi ok”: A kérdéseket nyitott kérdésként fogalmaztuk meg és így vált önálló változóvá a családi ok. A kérdöív azonban nem alkalmas arra, hogy a családi okok mögött meghúzódó indokokat, kényszereket mélyrehatóbban elemezzük.

\section{MoBILITÁs}

Az idősek helyzetét elemezve látható, hogy az élethelyzet kiemelt változóiban két év leforgása alatt nem következtek be meghatározó változások. Az idősek relatív jövedelembiztonságát a nyugdíj elősegíti. Az olyan esetekben, ahol az objektív mutatók az átlagtól sokkal rosszabbak (pl. egészségi állapot), az idősek szubjektíve jobbnak élik meg helyzetüket. A vizsgálat kiemelt változóiból három jellemzőt célszerü kiemelni: 
- az idősek szubjektív jólétét alapjaiban meghatározó tényező a családdal, társsal való támogató kapcsolat, melyet az idősek minden egyébnél jobban kitüntetnek

- a városi idősek speciális lakhatási helyzete, mely a relatív lakásnagyságban, a lakásegységbe való beszorulásban és a fenntartási költségek magas arányában érhetö tetten.

- Az egyedül élő idősek közül minden negyedik rendelkezik banki hitellel. A terhek vállalása valószínüleg a család támogatásának részeként jelentkezik, a gyermekek így juthattak hitelez, ha a szülő társult adósként. Az is feltételezhetö, hogy fedezetként az időskorú lakása került a tranzakcióba. A banki hitelek, devizahitelek kedvezőtlen alakulása az időskorúakat is „magával ránthatja”.

Jóléti programok tervezése során a fenti tényezőket minden esetben figyelembe kell venni, pl. a családi szolidaritást támogató rendszerekkel, generációk közötti szolidaritást segítő szolgáltatásokkal, pl. családsegítésben, időseket támogató családtagok laikus képzésének támogatásával, önkéntes szolgáltatások fejlesztésével.

A lakásmobilitás erősödése sok tényező függvénye. Az idősek nem szívesen szabadulnak meg életük munkájának eredményétől, még abban az esetben sem, ha a lakás fenntartása megélhetésüket komolyan veszélyezteti, de a megfelelő lakhatási lehetöség kiválasztására minden esetben jótékonyan hat, ha vannak megfelelőbb lakások (pl. nyugdíjasház, lakóövezet).

\section{IRODALOM}

1. Anne-Marie Guillemard(1999.): Megöregedés és kirekesztetté válás, Szociológiai Figyelö II-III. 1-2. sz.

2. Bukodi Erzsébet (2004.): Idősek társadalmának rétegződése. In: Időskorúak Magyarországon. KSH Budapest.

3. Durkheim E. (1986): A társadalmi munkamegosztásról MTA Szociológiai kutatóintézet.

4. Giczi Johanna(2008.): Szubjektív jólét időskorban in: Grádics Ágnes (szerk) Aktív időskor tanulmánykötet, KSH Budapest.

5. SPÉDER Zsolt (2005.): Az európai családformák változatossága, Századvég, $37 \mathrm{sz}$.

6. Országos Lakosság Egészségügyi Felmérés (2003.). www.omszk.hu (letöltés ideje: 2010, november. 10.)

7. Lakossági Egészségfelmérés Tiszavasvári Kistérség (2007.) http://193.225.50.35/dokumentum/MikroLEF2007/MikroLEF-2007_Tiszavasvari.pdf (letöltés ideje: 2011. 11.12.)

8. TÁRKI Háztartásmonitor http://www.tarki.hu/hu/research/hm/index.html (letöltés ideje: 2011.11.12.) 